\title{
Clause complexing in systemic functional lingustics - towards an alternative description
}

Thomas Hestbæk Andersen* (D) and Alexandra Emilie Møller Holsting

* Correspondence: thandersen@sdu. dk

Department for Language and Communication, University of Southern Denmark, Campusvej 55, DK - 5230 Odense M, Denmark

\begin{abstract}
This article examines Halliday \& Matthiessen's systemic functional description of expanding clause complexing. As a perspective, their description is compared to the Cardiff Grammar's treatment of clause combining. In particular, the article discusses the Hallidayan approach to the subordinate clause in a hypotactic clause complex: functionally speaking - and contrary to Halliday and Matthiessen's claims - it is far from convincing that a subordinate clause upholds its functional meanings, i.e. its functions as a 'move' (interpersonal meaning), a 'figure' (experiential meaning) and a 'message' (textual meaning); and systemically speaking, it is problematic to see why all hypotactic clause complexes are agnates with paratactic clause complexes, and why no subordinate clauses in hypotactic clause complexes could be said to be agnate with a prepositional phrase. In the final part of the article, we shall provide principles for a solution to the problematic issues at stake in the Hallidayan approach.
\end{abstract}

Keywords: Clause complex, Hypotaxis, Expansion, Figure, Move, Message

\section{Introduction}

In this article, we shall review the systemic functional description of clause complexing and point out some problematic issues in this description. Since these problems adhere to both the functional anchoring and the sytemic organisation of systemic functional linguistics, we shall examine clause complexing from both angles. The functional perspective deals with the lexicogrammatical categories clause and clause complex and their relatedness to the semantic categories of figure, move and message. The systemic angle is concerned with whether paratactic and hypotactic clause complexes are most adequately treated as agnates or whether the subordinate clause of a hypotactic clause complex share more features with constituents of the simplex clause. In the final part of the article, principles for an alternative description of clause complexing within a systemic functional framework will be sketched out, i.e. we shall provide an alternative description that accounts for the problems uncovered in our review. This alternative 
description is mainly anchored in our work in Danish and German, but it may with some modifications be suitable for the description of English as well.

The article will be based on Halliday's description of English, i.e. on the so-called IFG tradition of systemic functional linguistics (Halliday 1994; Halliday \& Matthiessen 2004; Halliday and Matthiessen, 2013); in other words, we shall not examine Fawcett's - or the Cardiff grammar's - description of clause combining in detail, but merely employ this as a perspective. Halliday, Matthiessen and other proponents of the IFG tradition have provided descriptions of clause complexing in numerous articles, chapters and books. We shall, however, mainly and throughout refer to Halliday and Matthiessen's Halliday's Introduction to Functional Grammar (Halliday and Matthiessen, 2013), since this is the latest version of the most comprehensive and authoritative description of English lexicogrammar within the IFG tradition.

\section{The clause complex in IFG}

A clause complex is defined as a grammatical construction consisting of two or more (simplex) clauses and accounts for examples like the following (1-10) (see Halliday and Matthiessen 2013: 447 on "basic types of clause complexes"; an explanation of the use of Arabic numbers and Greek letters follows on the next page):

(1) [1] John didn't wait; [2] he ran away.

(2) $[\alpha]$ John ran away, $[\beta]$ which surprised everyone.

(3) [1] John ran away [2] and Fred stayed behind.

(4) $[\alpha]$ John ran away, $[\beta]$ whereas Fred stayed behind.

(5) [1] John was scared, [2] so he ran away.

(6) $[\alpha]$ John ran away $[\beta]$ because he was scared.

(7) [1] John said: [2] "I'm running away".

(8) $[\alpha]$ John said $[\beta]$ that he was running away.

(9) [1] John thought to himself: [2] "I'll run away".

$(10)[\alpha]$ John thought $[\beta]$ he would run away.

In its most abstract sense a 'complex' (be it a clause complex, a group complex or a word complex) displays a particular structure that differs from that of a 'simplex' (a single clause, a single group, a single phrase or a single word) in that it does not consist of different functional elements but of functional elements of the same kind. While we in a clause observe different functional elements (e.g. Subject, Finite and Predicator) forming a multivariate structure, what we see in the clause complex is a univariate structure where each functional element (each clause) stands in the same relation to the other functional elements (the other clauses) in the same structure: "each new element is related to the previous simply as the 'next' link in a series or chain" (Matthiessen et al. 2010: 235). In other words, in a multivariate structure the syntagmatic organization is one of constituency, i.e. all clause elements constitute a larger element of another kind, while a univariate structure is syntagmatically organised in terms of interdependency between elements of the same kind. Univariate structures, such as the clause complex, are in principle indefinite, since they allow for recursion; Halliday \& Matthiessen's system 
network for clause complexing therefore involves the system of RECURSION, which organises the choices 'stop' and 'go on'.

The system network in Fig. 1 displays two other simultaneous systems.

The lexicogrammatical ${ }^{2}$ system of TAXIs describes the relation between clauses according to their interdependency; two clauses may have equal status or unequal status. If their status is equal, they are related through parataxis (this is noted with Arabic numbers, viz. the clauses are numbered as $1,2,3$, etc. according to the sequence in which they occur); if their status is unequal, they are related through hypotaxis (this is noted with Greek letters, viz. the clauses are labelled as $\alpha, \beta$, $\gamma$, etc., according to their place in the dependency hierarchy), and they therefore constitute a superordinate and a subordinate clause. Clauses related through parataxis and the superordinate clause in a hypotactic clause complex (the $\alpha$-clause) uphold the interpersonal status of a 'free' clause, while the subordinate clause in a hypotactic clause complex (the $\beta$-clause) has the status of a 'bound' clause (cf. Halliday and Matthiessen, 2013: 170). The categories 'free' and 'bound' are the results of choices made in the interpersonal system of FREEDOM (Halliday and Matthiessen, 2013: 185). If a bound clause functions as part of another clause (as a constituent or part of a constituent, which e.g. is the case for restricted relative clauses), it is said to be 'embedded'. As opposed to clause complexes, constructions with embedded clauses form multivariate structures.

The lexicogrammatical system named LOGICO-SEMANTIC TYPE organises clauses according to the ideational relation between them; this relation can be either projecting or expanding, i.e. the figurative meaning of one clause can project the figurative meaning of the related clause (as an idea or a locution), or the figurative meaning of one clause can be expanded (: elaborated, extended or enhanced) by the figurative meaning of the related clause.

Examples (1-10) above illustrate the different types of clause complexing also shown in Table 1 below, which intersects TAXIS with LOGICO-SEMANTIC TYPE (cf. Halliday and Matthiessen 2013: 447).

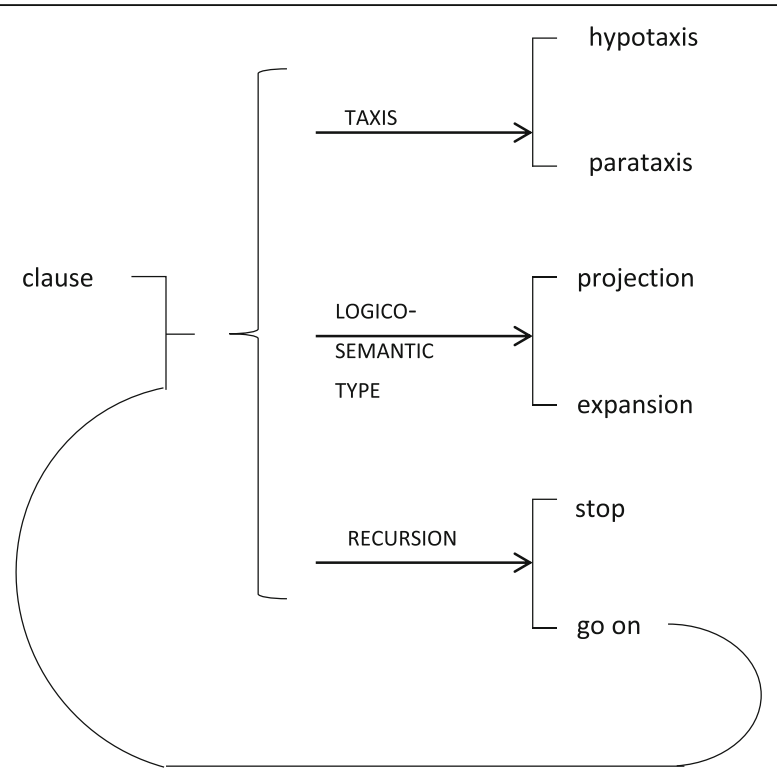

Fig. 1 The system network for clause complexing (Halliday and Matthiessen 2013: 438) 
Table 1 Intersection of TAXIS and LOGICO-SEMANTIC TYPE

\begin{tabular}{lll}
\hline & Expansion & Projection \\
\hline Parataxis & $(1),(3),(5)$ & (7), (9) \\
Hypotaxis & $(4),(6)$ & $(8),(10)$ \\
\hline
\end{tabular}

In this paper, we shall focus only on the expanding clause complex and leave out that of projection. Projection and expansion display some fundamental differences, since paratactic expansion is symmetrical (cf. Halliday and Matthiessen 2013: 446).

Expansion and projection are not features of the clause complex only. They are considered 'semantic domains', i.e. "semantic systems that are realised by grammatical systems operating in more than one place in the grammar" (Halliday and Matthiessen, 2013: 666). This is illustrated by Fig. 2 .

The figure shows how a sequence of figures (the rectangles) may be realised lexicogrammatically (i) in the experiential structure of the clause (whereby one figure is lexicogrammatically integrated in the other, cf. example (11) below), (ii) as a clause complex with a logical structure (indicated by the arrows) of either hypotaxis (indicated by the unlevelled rectangles, cf. example (12)) or parataxis (levelled rectangles, cf. example (13)) or (iii) as two conjunctively connected simplex clauses (cf. example (14)).

(11) He left before the vote ('A happened before the time of B')

(12) He left before the vote was taken ('A happened before B happened')

(13) He left and then the vote was taken ('A happened and then B happened')

(14) He left. Then the vote was taken. ('A happened. Then B happened')

As the figure and the examples show, we have four constructions, which to some degree can be said to be synonymous: in all examples, the two events, A and B, are related in terms of temporal posteriority. The four constructions differ with respect to

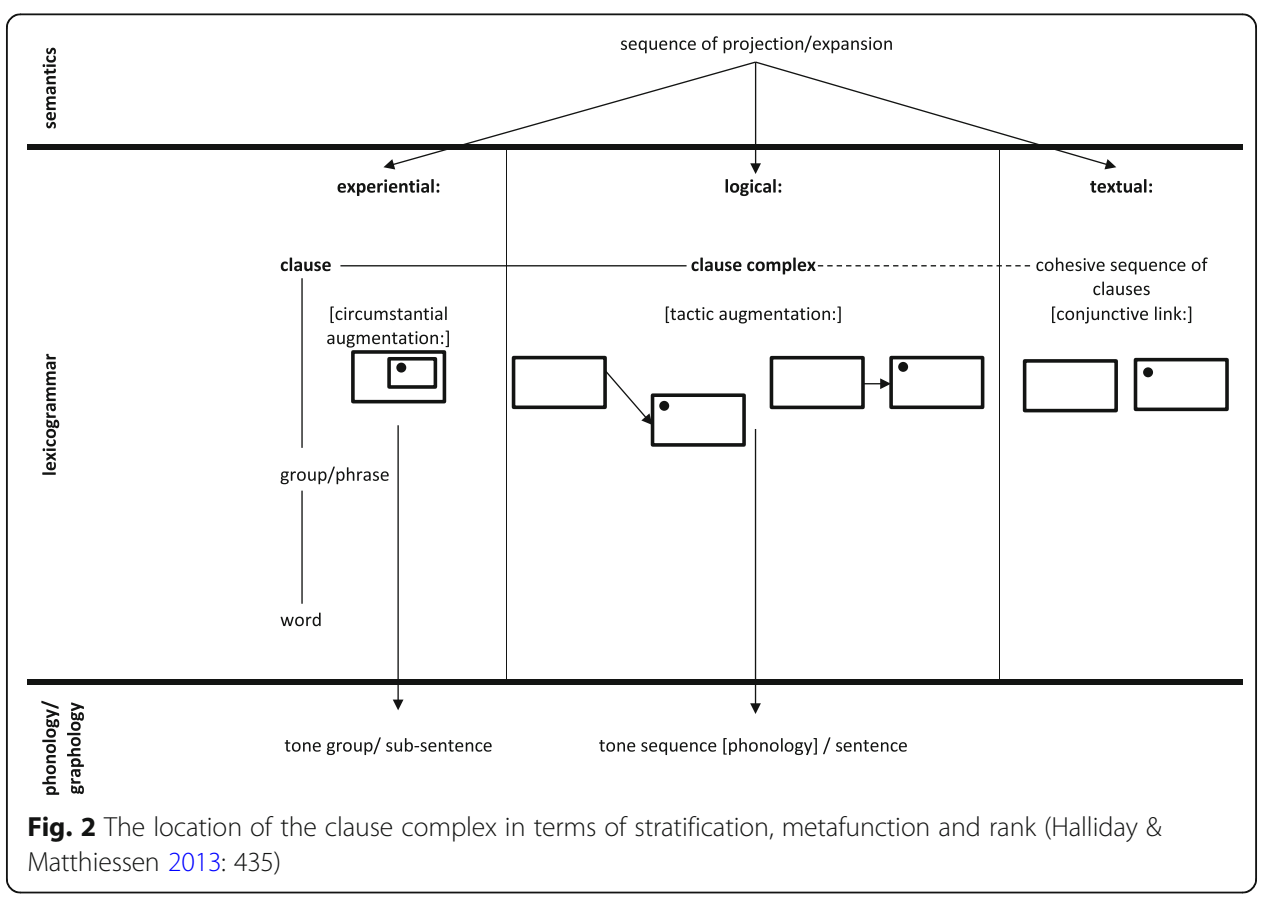


the way this logico-semantic relation is organised grammatically; in (11) as a simplex clause with a Circumstantial Adjunct, in (12) and (13) as clause complexes and in (14) as two independent simplex clauses.

As indicated by the Fig. 2, the description in IFG assumes agnateness between hypotactic and paratactic clause complexes. The two occur as terms in the system network of the clause complex (cf. Fig. 1), whereas the other constructions are located at other places in the grammar. This implies that the two constructions in (12) and (13) share all of their respective grammatical properties, except that of degree of interdependency between the clauses. This rests on the assumption that examples like (12) and (13) are univariate structures, whereas example (11) is a multivariate structure. In example (14) there is no structural relationship between the clauses. The reason why IFG does not treat the subordinate clause in (12) as a circumstantial Adjunct, on par with the prepositional phrase in (11), is thus based on a systemic argument. This argument, again, rests on a functional one, namely that the clauses combined in a clause complex all have the full potential of a clause, viz. the potential of message, move or figure no matter if the interdependency is one of parataxis or hypotaxis.

\section{Problems and inconsistencies with the clause complex in IFG}

In the following, we shall examine how IFG treats expanding hypotaxis with respect to the semantic categories of message, move and figure. Our examination of Halliday \& Matthiessen's description of hypotactic clause complexing is divided into two sections, namely one examining the more functional line of thinking in IFG, and one examining the more systemic argument. These two perspectives are of course intertwined, but for clarity's sake, we shall present and discuss them separately.

\section{An examination of the functional argument}

In the IFG tradition, the clause simultaneously organises a message (textual meaning), enacts a move (interpersonal meaning) and construes a figure (experiential meaning) (cf. Halliday and Matthiessen, 2013: 21, 83; Matthiessen et al. 2010: 72). ${ }^{3}$ As complexing is a matter of linking similar functional elements (making up a univariate structure), we should think that we in a clause complex of two clauses would be presented with two messages, two moves and two figures. This assumption seems to be unproblematic when we consider paratactic expansion such as (1), (3) and (5), but is less obvious when we consider examples of hypotaxis. We therefore need to examine IFG's line of reasoning and point out where there seems to be flaws.

According to SFL's metafunctional principle, the realisation relationship between the semantic categories of message, move and figure and the lexicogrammatical clause is used as an argument against the 'traditional' analysis of subordinate clauses as constituents of the superordinate clause. A traditional analysis would treat a subordinate enhancing clause like before the vote was taken in (12) He left before the vote was taken as an adverbial - in terms of IFG a circumstantial Adjunct - just like the prepositional phrase before the vote in (11) He left before the 
vote (cf. e.g. Quirk et al. 1978: 744). However, in the IFG tradition the subordinate clause in (12) functions as a hypotactically related clause in a clause complex; it is said to function as a clause in its own right - to keep its "clause-hood" (cf. Halliday and Matthiessen, 2013: 434), so to speak. An analysis of (12) according to IFG would look like this:

\begin{tabular}{ll}
\hline He left & before the vote was taken. \\
\hline a (superordinate clause in a hypotactic clause complex) & $\beta$ (subordinate clause in a hypotactic clause complex) \\
& $x$ (enhancing relation: before) \\
\hline
\end{tabular}

The description rests on the following functional reasoning:

[W] hile circumstantial elements [like the prepositional phrase in (11)] are part of the 'configurational' structure of the clause, clauses in clause complexes are part of a chain-like or serial structure. In the creation of text, we choose between augmenting a clause 'internally' by means of a circumstantial element and augmenting it 'externally' by means of another clause in a complex. The decision depends on many factors; but the basic consideration has to do with how much textual, interpersonal and experiential semiotic 'weight' is to be assigned to the unit: the more weight it has, the more likely it is to be constructed as an interdependent clause in a clause complex rather than a circumstantial [prespositional] phrase (or adverbial group) augmenting a clause (Halliday and Matthiessen, 2013: 434).

The difference between the augmenting clause in (12) and the prepositional phrase in (11) is thus based on the so-called clause-hood of the former:

[C]lause complexing always involves assigning clause-hood to a unit related to [a] clause through expansion or projection: the unit has the full potential of a clause, in terms of experiential, interpersonal and textual systems (Halliday and Matthiessen 2013: 434).

Clause-hood has the grammatical implication that a unit functions as the entry condition of the grammatical systems of THEME, MOOD and TRANSITIVITY. But it also has to do with the semantics of the clause. The difference between a prepositional phrase and a clause (e.g. when realising time as in (11) and (12)) is that a prepositional phrase "unlike a clause cannot construe a full figure, it cannot enact a proposition/proposal [move] and it cannot present a message" (Halliday and Matthiessen, 2013: 434). This quote indicates that each clause in a clause complex, be it paratactic or hypotactic, is seen as a realisation of a figure, a move and a message - as opposed to the prepositional phrase. This opposition could be expected to hold for $\beta$-clauses and embedded clauses as well, given that a $\beta$-clause upholds it clause-hood, which the embedded cannot be said to do (as it functions as an element in a clause). We shall examine this argument in the following, starting with the categories of figure and message and ending with the move.

Regarding the figure, we can observe that the validity of the claim that a prepositional phrase cannot present 'a full figure' depends on what is meant by 'full'. As shown in Fig. 2 and suggested by its accompanying examples, a sequence of figures can in fact be realised 
by a clause with a Circumstantial Adjunct in it, i.e. the prepositional phrase can realise the semantics of a figure. Now, whether this is 'a full figure' or some other kind of figure, is not addressed anywhere in IFG. In other words, the figure does not constitute a functional difference between a clause and a prepositional phrase.

Regarding the message, it can be assumed that a message is realised by all units that display a Theme-Rheme-Structure (we 'assume' this, as the message is not defined very clearly in $I F G$ ). Since a prepositional phrase does not display such a structure, it cannot be said to realise a message. In this respect, Halliday and Matthiessen's description of the message is tight. However, there are two problems with the message in relation to clause complexing. Both are related to our assumption that a message is organised whenever we can identify a Theme-Rheme structure in the clause.

The first problem is that both $\beta$-clauses and embedded clauses are said to have a thematic structure:

There is a thematic structure [...] in all major clause types; that is, all clauses expressing mood and transitivity, whether dependent or not (Halliday and Matthiessen, 2013: 125).

This means that - textually speaking - clause-hood is not only a feature of a $(\beta$-)clause functioning in a univariate structure but also of a constituent (i.e. the embedded clause) in a multivariate structure. This, of course, makes it difficult to distinguish $\beta$-clauses in hypotactic clause complexes from embedded clauses (although it is argued that for the embedded clause the "thematic contribution to the discourse is minimal and for practical purposes can be ignored" (Halliday and Matthiessen, 2013: 127)). And it is a theoretical problem, as it does not uphold the fundamental systemic boundary between two disparate structures; univariate and multivariate.

The second problem is that a thematic structure for the hypotactic clause complex as a whole is recognised: if a (bound) $\beta$-clause precedes a (free) $\alpha$-clause, it is analysed as Theme in the clause complex (with the $\alpha$-clause functioning as Rheme), whereby a clause complex in fact sets up three separate thematic structures (cf. the following example from Halliday and Matthiessen, 2013: 552):

\begin{tabular}{|c|c|c|c|c|}
\hline If & you & want a more substantial stuffing & add & a little mashed potato. \\
\hline Theme $_{1}$ & & & Rheme $_{1}$ & \\
\hline Theme $_{2}$ & & Rheme $_{2}$ & Theme $_{3}$ & Rheme $_{3}$ \\
\hline
\end{tabular}

[Such] examples [...] pose no great problem of analysis; the point to bear in mind is that there will be [three $]^{6}$ thematic domains - that of the clause nexus and that of the clause[s] (Halliday and Matthiessen, 2013: 552).

The analysis above, i.e. Halliday and Matthiessen's line of reasoning on this matter, raises uncertainty as to whether the clause complex realises one or two (or perhaps even three) messages. ${ }^{7}$ And again, we envisage a theoretical problem: when analyzing the clause complex as having a thematic structure of its own, Halliday and 
Matthiessen in fact treat what is in systemic terms a univariate structure of two similar elements (clauses) as a multivariate structure consisting of different functions

Regarding the move, it seems indisputable that a prepositional phrase functioning in a clause as a circumstantial Adjunct does not enact a move in itself but is a part of the move realised by the clause of which it is a constituent. The same holds for an embedded clause (cf. Halliday and Matthiessen, 2013: 172). However, whether this in fact distinguishes the prepositional phrase and the embedded clause from a $\beta$-clause in a clause complex is not lucidly clear. IFG shows how a clause comes to function as a move (of a particular kind) through choices made in the lexicogrammatical system of MOOD TYPE. The $\beta$-clause in a clause complex, however, does not enter into this system; in other words, whereas the structure of a free clause is the result of choices from MOOD TYPE, the structure of the bound clause (such as that of the $\beta$-clause) is not (cf. Halliday and Matthiessen, 2013: 172, 185). Thus, free clauses make a direct contribution to the development of exchange, either as a proposition (statement, answer) or as a proposal (offer, command), whereas bound clauses "are not presented by the speaker as being open for negotiation" (Halliday and Matthiessen, 2013: 170). Since the $\beta$-clause in a hypotactic clause complex is bound per se, it is hard to see how it should be able to enact a move, i.e. how the $\beta$-clause has (interpersonal) clause-hood.

In some systemic functional contributions of English, it has been suggested that the bound clause, when functioning as a $\beta$-clause, enacts a move in the same way as a free clause. Thus Matthiessen and Martin (1991: 25) assert that a $\beta$-clause is "immediately accessible to argumentation in discourse just as paratactically related clauses would be" (cf. also Matthiessen 1995: 326, 400); on the other hand, Matthiessen states that:

[f]ree clauses select freely for mood options, each one thus being capable of making an independent contribution to the development of dialogue [...]. In contrast to free clauses, 'bound' ones do not select freely for mood [...]. Interpersonally this means that they serve to support propositions and proposals rather than enact propositions and proposals (2002: 269; cf. Matthiessen 1995: 123).

As mentioned above, Halliday and Matthiessen (2013) like Matthiessen (2002) consider the bound $\beta$-clause to be non-negotiable, which would mean that its interpersonal status equates that of the embedded clause or the prepositional phrase. They do, on the other hand, suggest a kind of hierarchy for non-negotiability, in which embedded clauses are considered less negotiable than $\beta$-clauses. According to the same hierarchy, however, non-finite bound clauses ( $\beta$-clauses and embedded clauses) are "even further removed from the status of negotiability than finite ones" (Halliday and Matthiessen, 2013: 172; cf. Matthiessen 1995: 326 and Martin 1992: 40). The problem is that this description of (non-)negotiability conflates the opposition of hypotactic/embedded with that of finite/ non-finite, whereby e.g. the interpersonal potential of the non-finite $\beta$-clause becomes even smaller than that of the finite embedded clause (e.g. the defining relative clause in (17) I don't like men who lecture me).

If the $\beta$-clause, i.e. the bound clause in a hypotactic clause complex, is indeed non-negotiable - and this seems to be the prevailing line of thought in the IFG tradition - then we are left with two possible descriptions of its status (or not) as a move. Either the $\beta$-clause can be described as some integrated part of the move that is 
enacted by the superordinate, free $\alpha$-clause, or the $\beta$-clause can be said to function outside of the exchange structure, i.e. outside the (dialogic) sequence of moves making up an exchange of meaning. The first suggestion would mean that $\beta$-clauses and embedded clauses are identical with respect to their status as 'parts-of-moves', the second would imply that they differ, with embedded clauses as 'parts-of-moves' and $\beta$-clauses as standing outside of the exchange structure. In Halliday and Matthiessen, 2013, the authors seem to endorse the latter solution, which is illustrated by the following analysis (170):

\begin{tabular}{ll}
\hline Statement: give \& information \free: declarative & Supporting reason: presume \& information \bound \\
\hline Well, I'm still afraid of him & $\begin{array}{l}\text { 'cause he's bitten me. } \\
\text { I'm scared }\end{array}$ \\
\hline
\end{tabular}

In such cases, the speaker "presents the reason [the because-clause] not as a challengeable statement but as a supporting information to be taken for granted", and thereby she is "downgrading the issue of biting to the states of presumed information about what happened in the past" (Halliday and Matthiessen 2013: 171). The analysis introduces a new semantic category, namely 'the supporting move' (cf. also Matthiessen 2002: 269ff.). It is to be assumed that not only reasons but also other kinds of logico-semantic categories (time, condition, etc.) can be supporting in this sense, but since the term of the supporting move is not explained or defined anywhere, it leaves ample room for uncertainty.

However, no matter whether a $\beta$-clause is regarded as an integrated part of a move that is enacted by a free $\alpha$-clause, or a $\beta$-clause is said to function outside of the exchange structure, it is problematic to argue that a $\beta$-clause in a clause complex keeps its interpersonal clause-hood; interpersonal clause-hood is a feature of the clause when it functions as a move, and as we have seen, a $\beta$-clause does not, in fact, enact a move. The analysis suggested in Halliday and Matthiessen, 2013 surely does assign different interpersonal status to the prepositional phrase and the embedded clause on the one hand and the $\beta$-clause on the other, but it also assigns significantly different status to the $\beta$-clause and to the free clauses.

\section{An examination of the systemic argument}

Being a theory that emphasizes the paradigmatic organisation of language, SFL has a focus on the concept of choice between terms in a system. When modelling the grammar in systems and system networks, one will always hypothesize how different units and structures are related. A system with two terms is thus a hypothesis about the relatedness of these; by grouping them together and by excluding other units or structures from the system, the linguist makes a claim about the importance of different features. When "traditional formal grammar" (and other grammar theories) group the subordinate clause and the prepositional phrase together (as "circumstantial augmentation"), they make a certain assumption about what properties are important, and when IFG groups hypotactic and paratactic clause complexes together (as "tactic augmentation"), Halliday and Matthiessen also make such an assumption.

The systemic argument for IFG's description of the hypotactic clause complex is based on the idea that a hypotactic clause complex is agnate with a paratactic clause complex, 
which entails that the subordinate clause of a hypotactic clause complex is not systemically related to (group formed) constituents of the simplex clause, e.g. to prepositional phrases. This argument - and a brief critique hereof - can be illustrated with the examples also used in the previous section:

(11) He left before the vote.

(12) He left before the vote was taken.

(13) He left and then the vote was taken.

(14) He left. Then the vote was taken.

The reasoning rests on the assumption that examples (12) and (13) are agnates, whereas examples (11) and (12) are not, and if we treat (11) and (12) as agnates, we allegedly ignore how the lexicogrammar is actually organised.

This is very clear in the debate between Huddleston in his review of the first edition of IFG (1988) and Matthiessen and Martin's response (1991). Huddleston presents a list of features and grammatical reactances that are shared by (11) and (12) and suggests that the before-clause in (12) is more appropriately treated as a circumstantial Adjunct parallel with the prepositional phrase in (11), i.e. as an embedded clause in a multivariate structure. Huddleston lists the following features (we shall return to some of these in the following section):

- Both can be fronted.

- Both can appear in a cleft construction.

- Both can be in the focus of an interrogative.

- They can be coordinated.

To Huddleston, this means that the prepositional phrase and the subordinate clause function in the same way - as circumstantial augmentations of the simplex clause and consequently, the subordinate clause should be seen as systemically related to the prepositional phrase, not to the paratactically related clause.

To Matthiessen and Martin, however, these features do not entail that the subordinate clause should be seen as embedded; and they argue that by doing so, Huddleston

divorces clause combinations of this kind [example (12)] from paratactic clause complexes such as [13], whereas the two are brought together in Halliday's analysis, which operates with hypotactic and paratactic clause complexes. In Halliday's interpretation, the combination [in (12)] would be related to the paratactic complex in [13]. In Huddleston's interpretation, this relationship would be completely lost (Matthiessen and Martin 1991: 25).

Matthiessen and Martin acknowledge that "there will always be potentially conflicting criteria when we group constructions together into agnation sets" - i.e. there may be some properties shared by the subordinate clause and the prepositional phrase - but we should set up the agnation set "that provides us with the most powerful generalization" (Matthiessen and Martin 1991: 25). They consider the similarities between the subordinate 
clause and the prepositional phrase pointed out by Huddleston less adequate with respect to this compared to the ones between parataxis and hypotaxis pointed out by Halliday.

Matthiessen and Martin do, however, acknowledge that examples like (12) should be seen as somewhat intermediate between (11) and (13), and they suggest that this intermediate position could be accounted for by analysing examples like (12) as both a multivariate and a univariate structure ${ }^{8}$; according to their suggestion, example (12) would be analysed as follows (cf. Matthiessen and Martin 1991: 29):

\begin{tabular}{|l|l|l|l|}
\hline & He & left & $\begin{array}{l}\text { before the vote was } \\
\text { taken }\end{array}$ \\
\hline Experiential & Actor & Process>material & Circumstance>time \\
\hline Logical & $\alpha \longrightarrow \beta$ \\
\hline
\end{tabular}

This analysis further concurs with Martin's (1988) suggestion of two different angles on clause combining: a synoptic one that treats lexicogrammatical constructions as planned and a dynamic one that focuses on their linear emergence and development. The synoptic view is suitable when it comes to experiential patterns like the ones in the simplex clause, because the Process determines the necessary number and the types of Participants in the clause from the beginning, so to speak. The dynamic view makes more sense when it comes to logical recursive structures where the construction can be expanded continuously in the running text. A double analysis of hypotactic clause complexes was in fact suggested in earlier works of both Halliday (1981: 41) and Huddleston (1981), but no such complementary analyses of hypotactic clause complexes have ever been incorporated in IFG. The reason might be that this double analysis is theoretically problematic, as it treats a grammatical structure as both univariate and multivariate (we shall return to this below).

With Thompson, Matthiessen evaluates clause complexing in "traditional grammars" and here presents another reason for (11) and (12) not being agnates. They argue that traditional grammars usually consider examples like the before-clause in (12) as adverbial clauses because such grammars only distinguish two kinds of clause complexing: coordination and subordination; subordinate clauses are then held to be constituent clauses. To Matthiessen and Thompson, this view is problematic, since it equates class (a particular word order in the clause ${ }^{9}$ ) with function (constituent in the main clause) (Matthiessen and Thompson 1988). Thus, traditional grammars foreground the possibility of rephrasing the subordinate clause in (12) with a prepositional phrase like the one in (11):

[I]f we paraphrase our examples using a prepositional phrase functioning as an adverbial [Adjunct in IFG-terms], the result is a grammatical metaphor (...) [e.g.] Before leaving Krishnapur to escort his wife to Calcutta, the collector took a strange decision. $\rightarrow$ Before his departure from Krishnapur to escort his wife to Calcutta, the collector took a strange decision. Rewording the "adverbial clause" with a prepositional phrase to show that it is an adverbial does not show that at all; it shows that the result of representing the event of leaving as if it were an adverbial is a metaphor (Matthiessen and Thompson 1988: 280). 
Contemplating this argument, we agree with Butler that

it seems to confuse syntactic function with semantic (...) import: there seems to be no necessary contradiction between the claim that [before his departure from Krishnapur] is metaphorical and the claim that [before leaving Krishnapur], in terms of its structural function, is an adverbial clause. (Butler 2003: 281)

If anything, the argument should be that before his departure from Krishnapur is not an adverbial/Adjunct - and there is nothing in Halliday and Matthiessen 2013 that suggests that this is not in fact the case. Thus, the claim that examples (11) and (12) are not agnates cannot rest on a lack of paraphraseability (which is obviously there, and which is also predicted in Fig. 2).

Lexicogrammatical agnation concerns 'closeness' to other possible lexicogrammatical constructions (Halliday and Matthiessen, 2013: 31), and Halliday and Matthiessen suggest considering the different lexicogrammatical realisations of the sequence as points on a scale, where the poles are occupied by circumstantial augmentation and conjunctive link, respectively, and where tactic augmentation lies between the two:

But the clause complex is in fact not a single point on this scale; it covers two regions of the scale: closer to the pole of circumstantial augmentation, there are clause combinations where one clause is dependent on a dominant clause, the two thus being of unequal status (...); closer to the pole of cohesive sequences, there are clause combinations where the two clauses are interdependent on one another, the two having equal status. (Halliday and Matthiessen, 2013: 434-5).

While the scalar thinking may account for the fact that the hypotactic augmentation shares some properties with the circumstantial one, and the paratactic some with the cohesively related simplex clauses, the organisation of the grammar, in multivariate and univariate structures, delimits the degree of scalarity. The structures in question are either multivariate or univariate; paratactic structures cannot be 'more univariate' than hypotactic ones. Hypotactic and paratactic clause complexes go together in lexicogrammar because they share the same structural properties, and in the system for TAXIS (cf. the system network in Fig. 1), they are therefore considered agnates.

Fawcett identifies a further problem with Halliday \& Matthiessen's claim that a hypotactic clause complex (such as (12)) is agnate with a paratactic clause complex (such as (13)), namely that we can observe a significant discrepancy regarding the logico-semantic relations that can be established by means of coordinating and subordinating conjunctions, respectively (Fawcett 2000). This can be illustrated with the domain of temporal conjunctions. Halliday \& Matthiessen list the set of temporal conjunctions (cf. Halliday and Matthiessen, 2013: 477) that are shown Table 2.

The table illustrates

(i) that the hypotactic clause complex can realise temporal meaning in a more delicate way than the paratactic clause complex, since the subordinating temporal conjunctions allow us to distinguish between 'extent', 'point' and 'spread'; in other words, we do not have the same range of choices when we choose parataxis in the 
Table 2 Categories of enhancement and principal markers (shortened version)

\begin{tabular}{|c|c|c|c|c|}
\hline & Category & Meaning & Parataxis & Hypotaxis \\
\hline \multirow[t]{5}{*}{ Temporal } & same time & A meanwhile $B$ & $\begin{array}{l}\text { (and) meanwhile } \\
\text { (when) }\end{array}$ & [extent] as, while \\
\hline & & & & $\begin{array}{l}\text { [point] when, as soon } \\
\text { as, the moment }\end{array}$ \\
\hline & & & & $\begin{array}{l}\text { [spread] whenever, } \\
\text { every time }\end{array}$ \\
\hline & $\begin{array}{l}\text { different time } \\
\text { (later) }\end{array}$ & A subsequently B & $\begin{array}{l}\text { (and) then; and + } \\
\text { afterwards }\end{array}$ & after, since \\
\hline & $\begin{array}{l}\text { different time } \\
\text { (earlier) }\end{array}$ & A previously B & $\begin{array}{l}\text { and/but }+ \text { before } \\
\text { that/first }\end{array}$ & before, until /till \\
\hline
\end{tabular}

system of TAXIS as we do when we choose hypotaxis, and this is in principle a problem, since TAXIS and LOGICO-SEMANTIC TYPE are said to be simultaneous and independently variable systems, and

(ii) that the coordinating conjunctions listed for temporal parataxis are not in fact coordinating conjunctions but combinations of a conjunction (and, but) and a Textual Adjunct (meanwhile, then, afterwards, before that, first). ${ }^{10} \mathrm{~A}$ conjunction (and, but) always establishes a paratactic structure, whereas a Textual Adjunct may occur in other types of structures as well, e.g. in a simplex clause (cf. example (14)).

As Fawcett states:

It is always possible, of course, to express a roughly equivalent meaning by a combination of the [conjunction] and and an Adjunct such as afterwards or during that time, etc. (...) But this is a very different matter, in terms of the systemic choices that are available (...) because the introduction of an Adjunct opens up a much larger range of possibilities than is available within the [conjunction] (Fawcett 2000: 327-8).

If we use a strict criterion, by which a conjunction is defined as the function that establishes a syndetic paratactic construction, the possible lexemes constitute a very small group: Quirk et al. (1978: 552) regard three conjunctions (and, or, but) as coordinators, while for and so that are "on the gradient between the 'pure' coordinators and the 'pure' subordinators". In other words, the empirical basis of the system network (cf. Fig. 1) is undermined, since most of the hypotactic clause complexes do not have a paratactic counterpart, and a lot of the logico-semantic meanings (e.g. most of the enhancing types of meaning) cannot be combined with parataxis.

Now, it could be argued that by taking this strictly syntactical approach, we ignore that the lexicogrammar is in fact presenting the paratactic relationship as temporal in examples like (13). However, in our opinion, the fact that there is a temporal relation is accounted for at a different place in the analysis, viz. in the textual description. As illustrated in Fig. 2 and as stated by Halliday and Hasan (1976: 227 ff.), the different logico-semantic relations (e.g. temporal relations) may hold both between single clauses with no structural relationship between them and between clauses in a clause complex. If we compare examples (13) and (14): 
(13) He left and then the vote was taken

(14) He left. Then the vote was taken

we see that then has the same function in both examples; it establishes a cohesive tie between the clauses. This is not different from other cohesive mechanisms such as reference, e.g.:

(15) Wash and core six cooking apples, and put them into a fireproof dish.

(16) Wash and core six cooking apples. Put them into a fireproof dish.

In (15) and (16) them establishes a reference that is independent of the grammatical construction in which it occurs. In our opinion, conjunctive relations should be interpreted in the same way.

\section{Towards an alternative description of clause complexing}

As discussed in the previous section, the hypotactic clause complex causes problems for Halliday and Matthiessen's description of clause complexing for a number of reasons:

- $\beta$-clauses do not differ from prepositional phrases (or embedded clauses) with respect to their ability to construe figures, which makes this criterion ineffective for singling out and grouping paratactic and hypotactic clause structures as an opposition to prepositional phrases.

- All major clauses - whether free or bound, whether embedded or hypotactically related - have a thematic structure, and this blurs the idea of the message.

- $\beta$-clauses and paratactically related clauses seem to behave very differently with respect to their relationship to the semantic category of the move. The common assumption seems to be that a $\beta$-clause does not realise a move. A distinction has been set between $\beta$-clauses and embedded clauses in terms of a negotiation hierarchy. However, this hierarchy also concerns the variable of finite/non-finite, meaning that non-finite $\beta$-clauses are less challengeable than finite ones. This raises the question as to whether it is finiteness or the distinction between hypotaxis and embedding that is of importance when it comes to the negotiability of a bound clause. The analysis of the $\beta$-clause as a supporting move, with the $\alpha$-clause realising the proposition or proposal on its own, seems functionally inappropriate, since some clauses analysed as $\beta$-clauses are in fact a crucial part of the proposition or proposal (cf. below). This means that these $\beta$-clauses are functionally no different from prepositional phrases or embedded clauses.

- On the one hand, the hypotactic clause complex does not constitute a univariate structure of the various meanings of the clause (i.e. figure+figure, move+move and message+message), and the idea of clause-hood, therefore, seems ambiguous; on the other hand, it is precisely this idea of clause-hood, i.e. the semantic categories of figure, move and message, that makes Halliday and Matthiessen treat the subordinate clause in a hypotactic clause complex as a non-embedded clause. They reject the 
so-called traditional analysis, but as demonstrated this rejection is problematic, since it gives rise to an inconsistent description of clause complexing (which furthermore - it could be argued - holds form over function).

- There is a systemic problem, since the number of possible conjunctions for hypotaxis and parataxis differs significantly; we do not have the same range of choices when we choose parataxis in the system of TAXIS as we do when we choose hypotaxis. This is - at least to some degree - problematic for the claim that the two are agnate terms in a system.

Our conclusion is that the description in IFG neither supports the functional nor the systemic argument in a consistent way.

As mentioned earlier, the clause complex analysis has been reviewed critically by Fawcett, and the Cardiff Grammar actually suggests a rather different analysis of constructions like examples (1)-(10). Fawcett treats all subordinate clauses as constituents of the other clause filling Circumstantial Roles (Adjuncts) in the case of expansion and Participant Roles (Complements) in the case of projection (Fawcett 2000: 28-9). Although the Cardiff Grammar solves some of the problems identified in IFG (cf. Butler 2003: 291 f.), Fawcett's description too could be accused for ignoring functional aspects of the clause complex - like the IFG analysis, the Cardiff Grammar-analysis implies that all subordinate clauses are functionally alike.

Our proposal for analysing subordinate expanding clauses within the framework of the IFG-model is based on the assumption that not all clauses treated as expanding $\beta$-clauses are alike. We thus agree with Matthiessen and Thompson (1988: 285), who warn us not to equal class with function and therefore not to analyse all subordinate clauses as embedded, but we reach a different conclusion. Our description takes advantage of the distinction between embedded clauses and $\beta$-clauses that is available in the IFG-model, but we suggest that the line between the two be drawn differently, based upon different functional features that we observe in the field of expanding $\beta$-clauses. We suggest that a functionally based differentiation between expanding embedded clauses and expanding $\beta$-clauses may also strengthen the systemic description. The proposal put forward in the following has been developed for and tested on German and Danish (Holsting 2008, Andersen and Holsting 2015) and we shall refer to those languages in the following and consider to what degree the qualities in these languages can be transferred to the description of English.

The functional issue has to do with the question of clausehood examined earlier. As pointed out, this is best discussed with reference to the interpersonal category move, since the experiential figure is not exclusively tied to the ranking clause, and since the textual message relates to all units displaying a Theme-Rheme structure - including embedded dependent clauses.

Earlier, we addressed how IFG treats the $\beta$-clauses with respect to negotiability. We encountered an inconsistency between the assumption that all clauses in clause complexes have the functional potential of a clause and hence realise moves, on the one hand, and the assumption that $\beta$-clauses as bound clauses are not open for negotiation, on the other. Instead of realising propositions or proposals (i.e. challengeable moves), $\beta$-clauses present "supporting information to be taken for granted" (Halliday and 
Matthiessen 2013: 171). Contrary to embedded clauses, which are considered a part of a challengeable move, the $\beta$-clauses are placed outside of the move realised by the $\alpha$-clause.

A distinction between expanding embedded clauses and $\beta$-clauses is only acknowledged at one place in the IFG-model, namely with respect to relative clauses, where defining relative clauses like (17) are seen as embedded and non-defining ones like (18) as $\beta$-clauses:

(17) I don't like men who lecture me.

(18) I don't like my uncle, who always lectures me.

The defining relative clause in (17) is a part of a statement, and if the relative clause is removed, the intention of the statement is altered (example (17) does not mean the same as I don't like men). The non-defining relative clause (the $\beta$-clause) in (18), on the other hand, presents additional information that is not a part of the challengeable statement realised by the superordinate clause. The statement can be reduced to the superordinate clause without changing the intention of the statement (I don't like my uncle). Here it seems reasonable to claim that the subordinate clause represents supporting information that should be taken for granted.

If we examine this feature with respect to other expanding subordinate clauses, we observe that some show the same properties as the defining relative clause, e.g.

(19) Andre Agassi never played tennis while he was high.

If we want to challenge this statement by contradicting it, we do not only challenge the superordinate clause - we challenge the content of both clauses. The statement in (19) cannot simply be reduced to Andre Agassi never played tennis. In order to account for this, we should see the move as covering both the superordinate and the subordinate clause. Similarly if we ask a question like:

(20) Did Andre Agassi ever play tennis while he was high?

we do not expect an answer relating only to the part Did Andre Agassi ever play tennis?

This pattern is no different from the one we see when Circumstantial Adjuncts occur in the form of a prepositional phrase:

(21) Andre Agassi never played tennis on Mondays.

where a contradiction like Oh yes he did, I saw him play last Tuesday would not make any sense.

This possibility of standing in the scope of the proposition or proposal was addressed also by Huddleston (1988), and it is related to other scope features as well. For instance, a Polarity or Modality Adjunct of the superordinate clause may have scope over an expanding dependent clause:

(22) Maybe the director left the party because he was bored. 
(23) The actor didn't participate in the second season of the show because he needed the money.

In (22) the meaning of the Modality Adjunct maybe does not contribute as a modalisation of the content of the superordinate clause (the director left the party). He did in fact leave the party, only the speaker is not sure about the reason. Similarly, in (23) where the Polarity Adjunct does not negate the superordinate clause (the actor did participate in the second season of the show), but the reason expressed in the because-clause. All in all, an analysis that treats the two clauses as 'complete', as standing in their own right, will have trouble explaining what the Modal Adjunct and the Polarity Adjunct do in the clause in which they are placed. Only if the two clauses are seen as one interpersonal unit, our analysis can account for these issues.

This seems to be an argument in favor of treating all expanding subordinate clauses as embedded. However, the issues addressed above are not alike in all expanding subordinate clauses.

(24) The actor didn't participate in the second season of the show, although he needed the money.

(25) The parents wanted to go to Paris, whereas the children wanted to go to the beach.

In (24) and (25) the challengeable statement is in fact the content of the superordinate clause - this does not change if we leave out the dependent clause. Likewise, the Polarity Adjunct in (24) 'belongs' to the superordinate clause - it cannot cross the border between the two clauses as we saw in (23). This seems to justify that the subordinate clauses in (24) and (25) are treated as supporting moves not as part of the challengeable move of the superordinate clause. With respect to this, (24) and (25) can be said to be examples of univariate structures where each clause stands as a functioning whole.

The two types not only show differences with respect to interpersonal features like the ones mentioned above. They also differ with respect to textual differences, for instance the possibility of standing in the scope of a textual Adjunct like only:

(26) He only got the money back because the parcel was damaged.

(27) He only got his money back, although the parcel was damaged.

In (26) the scope of only covers the because-clause ('he got his money back, but only because the parcel was damaged'), but in (27) only belongs to the superordinate clause ('he only got his money back, but we should have expected that he was indemnified in some other way as well'). Another textual feature is the possibility of theme predication that only holds for examples like (28), not for examples like (29):

(28) It was because the parcel was damaged that he got his money back.

(29) "It was although the parcel was damaged that he got his money back. 
The fact that expanding subordinate clauses react differently to theme predication is mentioned in IFG (2013: 122, 550, 553), but not elaborated on, and it has no consequences for the analysis. Since theme predication is possible for "any element having a representational function in the clause" (2013: 122), this could be an indication that subordinate clauses that allow for theme predication should in fact be considered elements with a representational function in (and not outside of) the (superordinate) clause.

The fact that subordinate expanding clauses can be grouped together in two groups according to the way they behave with respect to the criteria listed above seems to be functionally relevant and should therefore be accounted for in our grammatical description. Our suggestion is to treat examples like (19), (22), (23) and (26) as embedded and the whole structure as multivariate, and examples like (24), (25) and (27) as $\beta$-clauses and the whole structure as univariate. This suggestion differs from the double analysis suggested by Matthiessen and Martin and from Fawcett's analysis of subordinate expanding clauses as Adjuncts, since these analyses do not differentiate between the subordinate clauses in the examples above. Martin (1988) has however touched upon a differentiated view on the field and presents a division based on the subordinating conjunctions that introduce the subordinate clause, which is shown in Table 3.

Our proposal for Danish and German assumes a similar division of the subordinate expanding clauses. It should be noted that Danish and German differ from English by making a formal distinction between what is called the main and subordinate clause word order. In Danish the difference has to do with the placement of Modal Adjuncts and Polarity Adjuncts:

(30) Peter er ikke blevet syg. ('Peter has not become sick')

(31) ...fordi Peter ikke er blevet syg. ('...because Peter has not become sick')

In the main clause in (30), the Polarity Adjunct $i k k e$ is placed after Subject and Finite (these may occur in any order) and in the subordinate clause in (31) it is placed between Subject and Finite. In German, the difference is even more explicit (cf. (32) and (33)).

Table 3 (after Martin 1988: 104-5)

\begin{tabular}{lll}
\hline Embedded & Embedded or hypotactic & Hypotactic \\
\hline after & as & although \\
as if & before & directly \\
as long as & for & except that \\
because & of & since \\
in so far as & so that & unless \\
in case & till & when \\
in order & until & whereas \\
in that & while & whether \\
once & & with \\
provided that & & \\
as soon as & & \\
such that & & \\
\hline
\end{tabular}


(32) Peter ist nicht krank geworden. ('Peter has not become sick')

(33) ...weil Peter nicht krank geworden ist. ('...because Peter has not become sick')

Here, the Finite is placed in the second position in the main clause, and in the last position in the subordinate clause. These formal differences co-occur with functional differences (clauses with subordinate word order is typically bound, clauses with main word order is typically free), but there are exceptions. While the word order may signal dependency, it does not in itself indicate whether a subordinate clause behaves like a supporting move or part of a move (cf. above).

When analysing both Danish and German data, we can establish that some logico-semantic categories are exclusively embedded or hypotactic, while others may be both. Thus, all temporal subordinate clauses behave like embedded clauses with respect to the reactances described above (cf, Hansen and Heltoft 2011: 1028; Pasch et al. 2003: 271ff.), whereas all concessive and adversative ones behave like $\beta$-clauses. Causal clauses, however, may be either-or. When we look further into their pattern, we observe that both languages make use of different subordinating conjunctions for the two categories. Embedded causal clauses are introduced by weil in German and fordi in Danish, whereas causal $\beta$-clauses are introduced by German da, zumal and Danish da, siden, eftersom. This seems to correspond to Martin's differentiation between because and since in Table 3.

(34) Er bleibt vielleicht zu Hause, weil er wieder krank geworden ist.

(35) Er bleibt vielleicht zu Hause, da er wieder krank geworden ist.

(36) Han bliver måske hjemme, fordi han igen er blevet syg.

(37) Han bliver måske hjemme, da han igen er blevet syg.

The scope of the Modal Adjunct vielleicht/måske ('perhaps') covers the subordinate clause in examples (34) and (36) ('perhaps the reason was that he has become ill again'), but not in (35) and (37) ('perhaps he stayed at home, since he has in fact become ill again').

Furthermore, both languages have a causal coordinating conjunction as well (German denn, Danish for, thi):

(38) Er bleibt vielleicht zu Hause, denn er ist wieder krank geworden.

(39) Han bliver måske hjemme, for han er igen blevet syg.

(notice the main clause word order in the clause introduced by denn/for). ${ }^{11}$

To make a causal clause challengeable as a move, German and Danish will present it in a main clause as in (38) and (39) and thus in a paratactic clause complex.

The fact that English because-clauses can in fact present challengeable moves, as pointed out by (Halliday and Matthiessen, 2013: 172) with respect to the example:

(40) That's the one I should have if I had any because it's jolly, isn't it?

may be seen as parallel to the causal parataxis in German and Danish. In English, subordinate clauses are traditionally defined with respect to the element that introduces 
Table 4 subordinate clauses behaving as... (Danish and German)

\begin{tabular}{|c|c|}
\hline \multicolumn{2}{|l|}{ Subordinate clauses behaving as... } \\
\hline Constituents (viz. embedded clauses) & Hypotactically related clauses (viz. $\beta$-clauses) \\
\hline $\begin{array}{l}\text {-All subordinate clauses related by a temporal } \\
\text { conjunction (e.g. Dan. når, Germ. wenn [when]) }\end{array}$ & $\begin{array}{l}\text {-All subordinate clauses related by a cause: result } \\
\text { conjunction (e.g. Dan. således at, Germ. so dass [so } \\
\text { that]) }\end{array}$ \\
\hline $\begin{array}{l}\text {-All subordinate clauses related by a manner: } \\
\text { comparison conjunction (e.g. Dan. ligesom, Germ. wie } \\
\text { [like]) }\end{array}$ & $\begin{array}{l}\text {-All subordinate clauses related by a condition: } \\
\text { concessive conjunction (e.g. Dan. selvom, Germ. } \\
\text { obwohl [although]) }\end{array}$ \\
\hline \multirow[t]{2}{*}{$\begin{array}{l}\text {-Some subordinate clauses related by a causal } \\
\text { conjunction (e.g. Dan. fordi, Germ. weil [because], } \\
\text { Dan. hvis, Germ. wenn [if].) }\end{array}$} & $\begin{array}{l}\text {-All subordinate clauses related by an addition: } \\
\text { adversative conjunction (e.g. Dan. mens, Germ. } \\
\text { während [while]) }\end{array}$ \\
\hline & $\begin{array}{l}\text {-Some subordinate clauses related by a causal } \\
\text { conjunction (e.g. Dan. da, eftersom Germ. da, zumal } \\
\text { [since].) }\end{array}$ \\
\hline $\begin{array}{l}\text {-Some subordinate clauses related by a conditional } \\
\text { conjunction (when these realise conditions relating to } \\
\text { the experiential meaning of the superordinate clause) }\end{array}$ & $\begin{array}{l}\text {-Some subordinate clauses related by a conditional } \\
\text { conjunction (when these realise interpersonal } \\
\text { meaning) }\end{array}$ \\
\hline
\end{tabular}

them, and since because is considered to be a subordinating conjunction, the becauseclause is considered subordinate in (40). It is however stated that some subordinate clauses can contain 'main clause phenomena' (cf. Green 1976) which indicate a freer, less dependent status (Halliday \& Matthiessen talk about "interactive features" which suggest that although the clause looks like a tagged bound clause, it is "closer to being free rather than bound" (Halliday and Matthiessen, 2013: 172)).

In Danish and in German, we see the following distribution of logico-semantic types with respect to the categories of embedded and $\beta$-clause suggested above in Table 4 .

The functional advantage of the analysis suggested here is that it makes it possible to account for the different interpersonal statuses of the subordinate clause as either realizing a part of a move (as embedded) or a supporting move (as a $\beta$-clause). There is however also a systemic advantage for dividing the field in this way.

First of all, by leaving out the embedded expanding clauses, we are left with $\beta$-clauses that without problems can be described as univariate structures, since both the $\alpha$ - and the $\beta$-clause can be considered functioning wholes without anything in the $\alpha$-clause having scope over the $\beta$-clause. In this respect, they are identical to paratactically related clauses. The difference with respect to taxis is then concerned with the weighing of these functional wholes against each other. This is typically described with reference to the concepts of 'equal' and 'unequal' (cf. Halliday and Matthiessen 1999; Halliday and Matthiessen, 2013: 439-440), whereby the equal weight means that both clauses can stand on their own, and unequal weight means that only the $\alpha$-clause can stand on its own. ${ }^{12}$

(41) Most children's fathers worked at an office, but my father worked at the studio.

(42) Most children's fathers worked at an office, whereas my father worked at the studio.

The two clause complexes share the logico-semantic relationship of adversativity but differ with respect to the status assigned to the adversative clause.

It should be noted that although the continuing clause in (41) and the $\beta$-clause in (42) share a common structure property (they are both clauses), this is not what defines 
them as agnates and thereby as terms in a system. Rather it is their status as functioning wholes that can then be assigned an equal or an unequal status with respect to the other functional whole of the construction.

The division of the expanding subordinate clauses may also - to some degree - solve the issue brought forward by Fawcett (cf. Table 2), that the logico-semantic choices available for paratactic clause complexes differ significantly from those available for hypotactic clause complexes, which makes the claim that both select from the same system inadequate. While the different logico-semantic categories presented in IFG show remarkable differences with respect to parataxis and hypotaxis, a more restricted view on hypotaxis results in fewer logico-semantic categories. As pointed out by Fawcett, no coordinating conjunction in English actually expresses temporal meaning in its own right. Parataxis established by and is not in itself temporal but needs to be qualified by other linguistic means that are not exclusively connected to the clause complex. However, since temporal clauses are considered embedded (according to the criteria above), there is actually no imbalance between parataxis and hypotaxis in that respect. To exemplify, Table 5 shows the logico-semantic categories available for parataxis and hypotaxis in Danish.

As the table shows, there is a high amount of overlap, but still some lexicogrammatical relations can only as it seems occur paratactically and others only hypotactically. Interestingly, however, it seems that Danish language users tend to fill in the gap with respect to concessive meaning, in that they often use the subordinating conjunction selvom as a coordinating one (cf. Christensen et al. in press).

A description like the one suggested here is to some degree identical to the one suggested by Morley (2004). Morley divides the bound clauses into two groups, integral and supplementary subordinate clauses. An integral clause "can be interpreted as operating as a constituent element within the structure of them main (superordinate) clause and functioning in the same manner as a phrasal constituent" (2004: 124). Such clauses would be embedded in terms of IFG, and this category covers nominal clauses (functioning as Subject or Complement), adjectival clauses (functioning as Modifiers in

Table 5 Logico-semantic categories available for parataxis and hypotaxis in Danish (after Andersen and Holsting, 2015: 279-287)

\begin{tabular}{|c|c|c|c|}
\hline & & Coordinating conjunction & Subordinating conjunction \\
\hline Elaboration & & $\begin{array}{l}\text { dvs. (abbreviation for } \\
\text { det vil sige) ('i.e.', 'that is') }\end{array}$ & $\begin{array}{l}\text { (relative clause; no subordinating } \\
\text { conjunction available) }\end{array}$ \\
\hline \multirow[t]{3}{*}{ Extension } & additive & og ('and') & $\begin{array}{l}\text { ligesom ('like'; not available as } \\
\text { sub in English) }\end{array}$ \\
\hline & alternative & $\begin{array}{l}\text { eller ('or'); enten - eller } \\
\text { ('either - or') }\end{array}$ & \\
\hline & adversative & men ('but') & hvorimod ('whereas'), mens ('while') \\
\hline \multirow[t]{4}{*}{ Enhancement } & causal & $\begin{array}{l}\text { for, thi ('because' as } \\
\text { coordinating conjunction) }\end{array}$ & $\begin{array}{l}\text { eftersom, idet, da, siden ('since', } \\
\text { 'inasmuch as') }\end{array}$ \\
\hline & consecutive & $\begin{array}{l}\text { så ('so' as coordinating } \\
\text { conjunction) }\end{array}$ & $\begin{array}{l}\text { så ('so' as subordinating conjunction), } \\
\text { sådan at, således at ('so that) }\end{array}$ \\
\hline & concessive & & selvom ('athough') \\
\hline & alternative condition & & $\begin{array}{l}\text { uanset om/at ('no matter if/that'), } \\
\text { hvad end, hvad enten - eller } \\
\text { ('irrespective of whether') }\end{array}$ \\
\hline
\end{tabular}


nominal groups) and adverbial clauses (functioning as Circumstances). The last group covers all IFG's enhancing $\beta$-clauses.

Supplementary clauses do not function as constituents of the superordinate clause as opposed to integral clauses, they can be removed "without affecting the grammaticality of the meaning content of the remaining main clause" (2004: 127). This group is further divided into adjunctive clauses and secondary proposition clauses. The first group covers bound clauses that add further information of a textual or interpersonal kind, e.g. comments to, statements of the validity of or connective leads into the superordinate clause:

(43) What is particularly annoying, she didn't even phone.

(44) As far as I am concerned, she didn't even phone.

(45) What is more, she didn't even phone.

This addresses the fact that although the clause complex is considered to be an ideational construction in IFG, the subordinate clause can in some cases be said not to have an ideational function with respect to the superordinate clause, but rather to serve a textual or an interpersonal function with respect to the meaning content of the superordinate clause. This distinction is sometimes treated as an opposition between external and internal connection, whereby an externally related $\beta$-clause relates to the $\alpha$-clause as a figure and the internally related one to the $\alpha$-clause as a move (cf. Halliday and Matthiessen, 2013: 484, Martin 1992: 217; Thompson (2005: 775) adds to the picture that it may also be related to the $\alpha$-clause as a message).

Morley's supplementary clauses are ideationally related subordinate clauses that "provide an additive, replacive or contrastive proposition relating to (the whole or just part of) the superordinate clause" (2004: 126). This category covers IFG's enhancing and extending $\beta$-clauses, e.g.:

(46) You can lie there all day, which wouldn't give you much exercise.

(47) The present treasurer, who has managed the finances excellently, ought to be reappointed.

(48) Besides having an enjoyable time, we also learned a great deal.

Compared to IFG, Morley's treatment of expanding subordinate clauses can be illustrated in Table 6.

While this description is identical to our suggestion in many ways, it differs with respect to the treatment of IFG's enhancing $\beta$-clauses. While Morley treats all such clauses as integral (and thereby embedded), we suggest dividing the field according to whether the subordinate clause serves as part of the move or as a supporting move.

All in all, we consider the proposal for treating subordinate clauses within the IFG-model described above better suited for accounting for the actual differences than the analysis suggested in IFG itself. It accounts for some highly relevant functional differences between subordinate clauses, and it furthermore establishes a stronger generalization with respect to the systemic argument. It solves if not all then at least some of the problems raised by different critics, and not unimportant: it does not confuse class with function. It acknowledges that although subordinate 
Table 6 Expanding subordinate clauses according to IFG and Morley 2004

\begin{tabular}{lllll}
\hline IFG & Embedded & $\beta$-clause elaborating & $\beta$-clause extending & $\beta$-clause enhancing \\
\hline Morley & $\begin{array}{l}\text { Integral adjective } \\
\text { clause }\end{array}$ & $\begin{array}{l}\text { Supplementary }> \\
\text { secondary proposition }\end{array}$ & $\begin{array}{l}\text { Supplementary }> \\
\text { secondary proposition }\end{array}$ & $\begin{array}{l}\text { Integral adverbial } \\
\text { clause }\end{array}$ \\
\hline
\end{tabular}

clauses share many formal features, they do not necessarily have the same function. Furthermore, it makes use of a distinction between embedded clauses and $\beta$-clauses that is already available in the model.

\section{Coda}

With the aim of making the system of clause complexing a powerful generalisation, we have here taken a step towards a nuanced description, in which we treat those bound expanding clauses that behave like constituents as constituents and treat those that do not as clauses in the IFG-sense (cf. Andersen and Holsting, 2015). Such a description will fully support the functional and systemic foundations of systemic functional linguistics.

\section{Endnotes}

${ }^{1}$ The term 'recursion' is however also used with reference to the multivariate structures, since rank shifting in some sense allows us to start over in a system network. This type of recursion is labelled 'cyclic recursion' (Halliday 1981: 40) or 'incursion' (Caffarel et al. 2004: 34), as opposed to the recursion in complex structures which is called 'linear recursion' (Halliday 1981: 40) or simply 'recursion' (Caffarel et al. 2004: 34).

${ }^{2}$ There is some uncertainty as to whether the categories forming TAXIS and LOGICO-SEMANTIC TYPE are indeed lexicogrammatical or semantic or both at the same time (cf. Butler 2003: 290).

${ }^{3}$ The message, the move and the figure and the way these semantic categories are realized linguistically in the clause are crucial to the classification of systemic functional linguistics as a functional linguistic theory; in other words, we are contemplating key concepts in this article. In (very) short, the argument goes as follows: since the clause configures textual, interpersonal and experiential meaning and thereby functions simultaneously as a message, a move and a figure in the exchange of meanings, i.e. in the communication between two or more interlocutors, systemic functional linguistics regards grammar as motivated, not arbitrary (cf. Butler 2003: 44-45); hence language is first and foremost regarded as a system of functions/meanings, and thereby systemic functional linguistics fulfills the functional hypothesis (cf. Hasan 1985: 6).

${ }^{4}$ The IFG tradition labels this approach "traditional"; however, IFG stands fairly alone with their approach to subordination, which means that 'traditional' here equates 'non-IFG' (cf. Butler 2003).

${ }^{5}$ Martin (1992) has a slightly different approach to the one just discussed, since he states that: "[t]he unit message will be adopted here, where this is realized as a ranking clause that is neither a projection, nor a hypotactically dependent elaborating clause. This means that locutions and ideas, elaborating $\beta$-clauses and all embedded clauses will be treated as part of messages rather than as conjunctively related units in their own right" 
(Martin 1992: 235). In Martin's view, only a sub-group of bound clauses (viz. extending and enhancing $\beta$-clauses) realizes messages. This again challenges Halliday and Matthiessen's idea of the (textual) 'clause-hood' quality of any $\beta$-clause.

${ }^{6}$ The text says 'two'; we assume that Halliday and Matthiessen mean three, since their analysis identify three separate thematic structures.

${ }^{7}$ One quote in IFG could solve the problem of whether a clause complex is considered a realization of one or two messages: "Clauses are linked to one another by means of some kind of logico-semantic relation to form clause complexes representing sequences of figures (or moves) that are presented as textually related messages" (Halliday and Matthiessen 2013: 428) Unfortunately, the quote is ambiguous, since the enhancing that-clause could specify both "sequence" and "figure/move".

${ }^{8}$ This would be parallel to the analysis of the nominal group that is analysed in terms of both an experiential and a logical structure (Halliday and Matthiessen 2013: 364ff.).

${ }^{9}$ This of course only goes for languages that make a formal distinction between main clauses and subordinate clauses.

${ }^{10}$ The word order of English to some degree allows for such fuzziness with respect to the boundaries of the conjunction, since there is no clear topological border to mark the end of a conjunction. In V2-languages like German or Danish where the declarative clause is organized topologically differently, we cannot argue that parallel word combinations like und dann/og så function as conjunctions, since the Adjunct part always fills the position of a clause constituent, whereas the conjunction part does not.

${ }^{11}$ This picture that divides the field of cause between weil/fordi, da/da and for/denn is somewhat idealized, since - especially in spoken discourse - many speakers tend to use weil/fordi in all cases. So while the use of $d a / d a$ is exclusively connected to $\beta$-clauses and denn/for can only be used as coordinating conjunctions, fordi/weil can be used in all categories. However, only fordi/weil can be used in embedded cause clauses.

${ }^{12}$ The important difference with respect to embedding does not concern the dependent clause, since neither $\beta$-clauses not embedded clauses can stand on their own - it concerns the superordinate clause, since the $\alpha$-clause in a hypotactic clause complex can in fact stand on its own, as its meaning is not restricted by the $\beta$-clause, whereas the superordinate clause cannot stand on its own without its embedded clause. By removing the embedded clause, we change the meaning (cf. the relative clause example in (17) and the embedded clause in (19)).

Abbreviation

IFG: An Introduction to Functional Grammar

\section{Acknowledgements}

We are grateful for the helpful comments from our colleagues in the international systemic functional milieu, which we received in a paper presentation on this subject at the 27th ESFLC in Salamanca, 2017. We also wish to thank the anonymous reviewers for their guidance and comments.

Availability of data and materials

The research has been carried out with empirical data from The British National Corpus (https://corpus.byu.edu/bnc/) and KorpusDK (http://ordnet.dk/korpusdk).

\section{Authors' contributions}

Each of the two authors has contributed $50 \%$ to this work. Both authors read and approved the final manuscript. 
Alexandra Emilie Møller Holsting, Ph.D., is an associate professor at the University of Southern Denmark. Her research focusses on systemic functional description of German and Danish lexicogrammar.

\section{Competing interests}

The authors declare that they have no competing interests.

\section{Publisher's Note}

Springer Nature remains neutral with regard to jurisdictional claims in published maps and institutional affiliations.

Received: 8 March 2018 Accepted: 2 July 2018

Published online: 29 August 2018

\section{References}

Andersen, Thomas Hestbæk and Alexandra Holsting. 2015. Teksten i grammatikken. Odense: Syddansk Universitetsforlag. Butler, Christopher S. 2003. Structure and function - A guide to three major structural-functional theories. Part 2: From clause to discourse and beyond. Amsterdam: Benjamins.

Caffarel, Alice, James R. Martin, and Christian M.I.M. Matthiessen. 2004. Introduction: Systemic functional typology. In Language typology: a functional perspective, ed. Alice Caffarel, James R. Martin, and Christian M.I.M. Matthiessen, 176. Amsterdam: Benjamins.

Christensen, Marie $\mathrm{H}_{\text {, et }}$ al. in press, 2017. Does main clause word order affect attention to change in subordinate clauses? Linguistics.

Fawcett, Robin P. 2000. A theory of syntax for systemic functional linguistics. Amsterdam: Benjamins.

Green, Georgia M. 1976. Main clause phenomena in subordinate clauses. Language 53 (2): 382-397.

Halliday, M.A.K. 1981. Types of Structure. In Readings in Systemic Linguistics, ed. M.A.K. Halliday \& James R. Martin, 29-41. London: Basford.

Halliday, M.A.K. 1994. An introduction to functional grammar. 2nd ed. London: Arnold.

Halliday, M.A.K., and Ruqaiya Hasan. 1976. Cohesion in English. London: Longman.

Halliday, M.A.K., and Christian M.I.M. Matthiessen. 1999. Construing Experience Through Meaning. A Language-based Approach to Cognition. London: Continuum.

Halliday, M.A.K., and Christian M.I.M. Matthiessen. 2013. Halliday's Introduction to Functional Grammar. 4th ed. London and New York: Routledge.

Halliday, M.A.K., and Christian M.I.M. Matthiessen. 2013. An introduction to functional grammar. 3rd ed. London: Routledge.

Hansen, Erik and Lars Heltoft. 2011. Grammatik over det danske sprog. Odense: Syddansk Universitetsforlag.

Hasan, Ruqayia. 1985. Offers in the making: A systemic-functional approach. Macquarie University. In Mimeo: "Revised and enlarged version of a paper presented at the XIlth international systemic workshop".

Holsting, Alexandra. 2008. Det tyske sætningskompleks - en kritisk-konstruktiv diskussion af en systemisk-funktionel kategori og dens applikation på tysk. Københavns Universitet.

Huddleston, Rodney. 1981. Rank and Depth. In Readings in Systemic Linguistics, ed. M.A.K. Halliday and James R. Martin, 42-53. London: Batsford.

Huddleston, Rodney. 1988. Constituency, multi-functionality and grammaticalization in Halliday's functional grammar. Journal of Linguistics 24: 137-174.

Martin, James R. 1988. Hypotactic Recursive Systems in English: Towards a Functional Approach. In Systemic Functional Approaches to Discourse: Selected papers from the 12th International Systemics Workshop, ed. James Benson and William Greaves, 240-270. Norwood: Ablex.

Martin, James R. 1992. English text. System and structure. Philadelphia: Benjamins.

Matthiessen, Christian M.I.M. 1995. Lexicogrammatical cartography: English systems. Tokyo: International Language Science Publishers.

Matthiessen, Christian M.I.M. 2002. Combining clauses into clause complexes. A multi-faceted view. In Complex sentences in grammar and discourse. Essays in honour of Sandra A. Thompson, ed. Joan Bybee and Michael Noonan, 235-319. Amsterdam and Philadelphia: Benjamins.

Matthiessen, Christian M.I.M., and James R. Martin. 1991. A response to Huddleston's review of Halliday's introduction to functional grammar. Occasional Papers in Systemic Linguistics 5: 55-84.

Matthiessen, Christian M.I.M., Kazuhiro Teruya, and Marvin Lam. 2010. Key terms in systemic functional linguistics. London: Continuum.

Matthiessen, Christian M.I.M., and Sandra A. Thompson. 1988. The structure of discourse and 'subordination'. In Clause Combining in Grammar and Discourse, ed. John Haiman and Sandra A. Thompson, 275-329. Amsterdam and Philadelphia: Benjamins.

Morley, George D. 2004. Explorations in functional syntax. London and Oakland: Equinox.

Pasch, Renate, et al. 2003. Handbuch der deutschen Konnektoren. Linguistische Grundlagen der Beschreibung und syntaktische Merkmale der deutschen Satzverknüpfer (Konjunktionen, Satzadverbien und Partikeln). In Schriften des Instituts für Deutsche Sprache 9. Berlin: de Gruyter.

Quirk, Randolph, Sidney Greenbaum, Geoffrey Leach, and Jan Svartvik. 1978. A grammar of contemporary English. 7th ed. London: Longman.

Thompson, Geoff. 2005. But me some buts: A multidimensional view of conjunction. Text 25: 763-791. 